\title{
The Current Situation and Problems of Expenditure of public safety - Based on the Provincial Panel Data
}

\author{
Cao Yongsheng \\ Donghua University \\ Shanghai, 201620, China
}

\begin{abstract}
In the past few years, a substantial increase in governmentexpenditure on public safety,In this paper, Chinese Almanac in 2007 opened the public security spending as a starting point,Through data analysis of the current status of China's public security spending, find our current problems such as public safety, local government spending overburdened; different provinces in different public safety expenditure performance; public safety spending inequality; the performance of anti-growth under the growth spending and other issues.
\end{abstract}

Keywords-component; formatting; style; styling; insert (key words)

\section{INTRODUCTION}

China is currently the most dramatic economic variables change, but also in period of the most dramatic changes in the social structure, group eventsrepeated outbreaks and confrontational social contradictions intensify.In the first half of 2014, China's public security system is seriously challenged, violence of Kunming Railway Station, group events of Maoming, one by one the public safety issues pulled the hearts of people across the country.However, it also found that social instability situation has not been significantly improved, on the contrary, they seem to become more and more severe, and the number of incidents of crime and population remains highunder the circumstance ofpublic security spending continues to grow. Especially in the midwest of China, a large-scale outbreak of mass frequency much higher than the economically developed regions.

\section{THE CURRENT SITUATION AND PROBLEMS OF EXPENDITURE OF PUBLIC SAFETY}

Our public safety issues do have national and regional reason, but we have to admit that expenditure performance issues of public safety and public safety problems caused by public safety spending inequality are worth conducting research for policy makers and theorists.

\section{A. the public security spending}

Prior to 2007, the "Fiscal" part of the 《China Statistical Yearbook》 is not listed the "public safety spending" project, only the national and local "expenditure of public security department " and " expenditure of armed police " project. After 2007, the department of " expenditure of public safety "replaced"expenditure of public security department " and " expenditure of armed police ".

For now, the government and the academia did not give serious understanding for the concept of public security spending, most understood as " fee of stabilitymaintenance."

\section{B. the analysis of the status quo ofpublic safety}

spending of Chineseprovinces

In order to eliminate ethnic factors and other factors, this paper will remove the five ethnic minority autonomous regions, and choose other 26 provinces and two special administrative regions as analysis of sample.

Table 1: List of public security spending of Chineseprovinces (Unit: 100 million)

\begin{tabular}{|l|l|l|l|l|l|l|}
\hline & 2007 & 2008 & 2009 & 2010 & 2011 & 2012 \\
\hline $\begin{array}{l}\text { State financial } \\
\text { expenditure of public } \\
\text { safety }\end{array}$ & $3,486.16$ & $4,059.76$ & $4,744.09$ & $5,517.70$ & $6,304.27$ & 7.111 .60 \\
\hline
\end{tabular}

Source: 2008-2012, 《China Statistical Yearbook》 


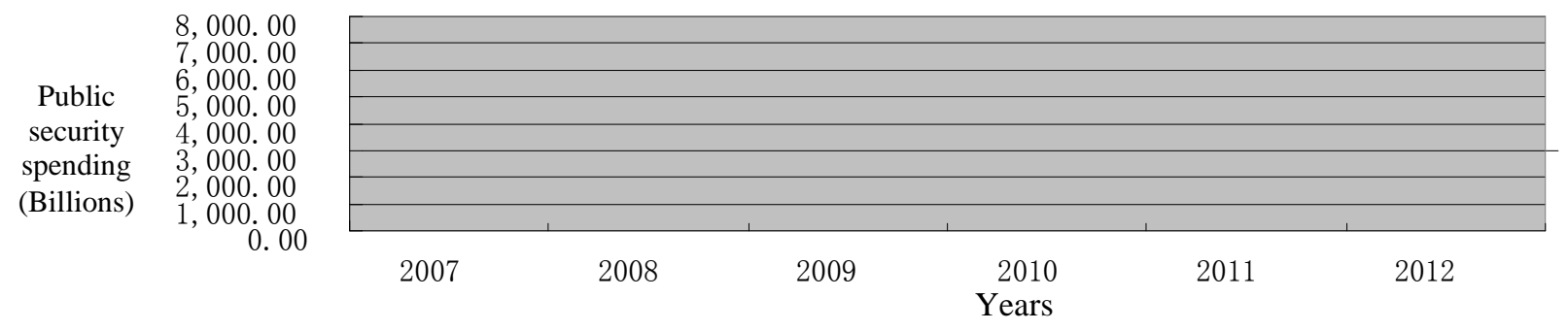

Figure 1: 2007-2012, China's public security spending growth

Source: 2008-2012, 《China Statistical Yearbook》

According to Figure 1 and Table 1, we can see that since the " ChinaStatistical Yearbook " opened public safety expenditures column, Chinese annual national public security spending shows a growing trend,7111,6 billion yuanof public safety expenditures in 2012 more figure above, public safety spending growth rate in six years to maintain a relatively stable level, we can predict that within the next two to three years, public safety spending growth rate will be maintained at this level. than doubled in 2007 of 348.616 billion yuan.From the

Table 2: Expenditure of public safety of the central government and local government

\begin{tabular}{|l|l|l|l|l|l|l|}
\hline & 2007 & 2008 & 2009 & 2010 & 2011 & 2012 \\
\hline $\begin{array}{l}\text { Expenditure of public safety of the } \\
\text { central government (million) }\end{array}$ & 607.83 & 648.63 & 845.79 & 875.2 & $1,037.01$ & $1,183.47$ \\
\hline $\begin{array}{l}\text { Expenditureof public safety of the local } \\
\text { government (million) }\end{array}$ & $2,878.33$ & $3,411.13$ & $3,898.30$ & $4,642.50$ & $5,267.26$ & $5,928.13$ \\
\hline
\end{tabular}

Source: 2008-2012, 《China Statistical Yearbook》

Table 3: The situation of the share of public security spending

\begin{tabular}{|l|l|l|}
\hline year & $\begin{array}{l}\text { Percentage of Central public security } \\
\text { expenditure }\end{array}$ & Percentage of local public security expenditure \\
\hline 2007 & 17.44 & 82.56 \\
\hline 2008 & 15.98 & 84.02 \\
\hline 2009 & 17.83 & 82.17 \\
\hline 2010 & 15.86 & 84.14 \\
\hline 2011 & 16.45 & 83.55 \\
\hline 2012 & 16.64 & 83.36 \\
\hline
\end{tabular}

Source: 2008-2012, 《China Statistical Yearbook》

From table 2 and table 3, we can see that, compared to the local government, the central governmentbear the main responsibility for public security expenditure.More

importantly, in some areas, expenditure of public safety has become the largest local fiscalexpenditures, seriously affecting local government expenditure allocation. 
Table 4: Public Security expenditures of Chinese Provinces (Unit: 100 million)

\begin{tabular}{|c|c|c|c|c|c|c|}
\hline year & 2007 & 2008 & 2009 & 2010 & 2011 & 2012 \\
\hline Beijing & 133.8 & 160.46 & 161.38 & 180.94 & 218.68 & 236.87 \\
\hline Hebei & 108.92 & 136.78 & 151.2 & 176.08 & 200.98 & 227.17 \\
\hline Tianjin & 53.88 & 65.85 & 73.49 & 84.92 & 100.41 & 111.92 \\
\hline Shanxi & 70.61 & 90.75 & 98.44 & 121.84 & 130.31 & 143.79 \\
\hline Liaoning & 126.77 & 147.58 & 154.16 & 191.29 & 210.29 & 228.8 \\
\hline Jilin & 61.02 & 71.95 & 98.19 & 109.3 & 118.81 & 135.67 \\
\hline Heilongjiang & 79.95 & 92.5 & 109.11 & 134.85 & 141.22 & 168.4 \\
\hline Shanghai & 134.33 & 149.57 & 163.41 & 187.25 & 206.11 & 221.08 \\
\hline Jiangsu & 210.73 & 252.88 & 284.75 & 326.8 & 371.4 & 407.78 \\
\hline Zhejiang & 173.79 & 199.62 & 216.98 & 260.67 & 290.87 & 319.03 \\
\hline Anhui & 72.52 & 86.89 & 105.32 & 119.48 & 128.58 & 149.15 \\
\hline Fujian & 76.56 & 91.6 & 99.47 & 120.6 & 144.74 & 162.39 \\
\hline Jiangxi & 65.15 & 75.29 & 86.22 & 107.49 & 123.9 & 141.71 \\
\hline Shandong & 156.21 & 173.26 & 197.37 & 244.03 & 274.69 & 317.38 \\
\hline Henan & 119.69 & 139.19 & 167.14 & 189.72 & 204.8 & 244.42 \\
\hline Hubei & 109.42 & 125.65 & 137.57 & 166.87 & 188.4 & 204.53 \\
\hline Hunan & 96.31 & 112.8 & 125.28 & 159.14 & 174.42 & 200.38 \\
\hline Guangdong & 340.77 & 393.21 & 432.99 & 495.8 & 569.85 & 621.39 \\
\hline Hainan & 18.82 & 24.25 & 32.88 & 43.94 & 53.23 & 57.11 \\
\hline Chongqing & 53.79 & 61.44 & 71.67 & 91.84 & 124.93 & 134.03 \\
\hline Sichuan & 125.03 & 153.14 & 182.79 & 218.38 & 246.07 & 272.63 \\
\hline Guizhou & 57.22 & 68.07 & 82.95 & 101.46 & 117.31 & 146.21 \\
\hline Yunnan & 84.61 & 106.51 & 134.56 & 145.42 & 165.32 & 185.88 \\
\hline Shanxi & 64.17 & 76.39 & 94.53 & 111.5 & 128.06 & 149.04 \\
\hline Gansu & 38 & 45.27 & 57.52 & 70.45 & 80.31 & 95.22 \\
\hline Qinghai & 15.99 & 20.38 & 26.08 & 35.48 & 35.1 & 40.31 \\
\hline
\end{tabular}

Source: 2008-2012, 《China Statistical Yearbook》

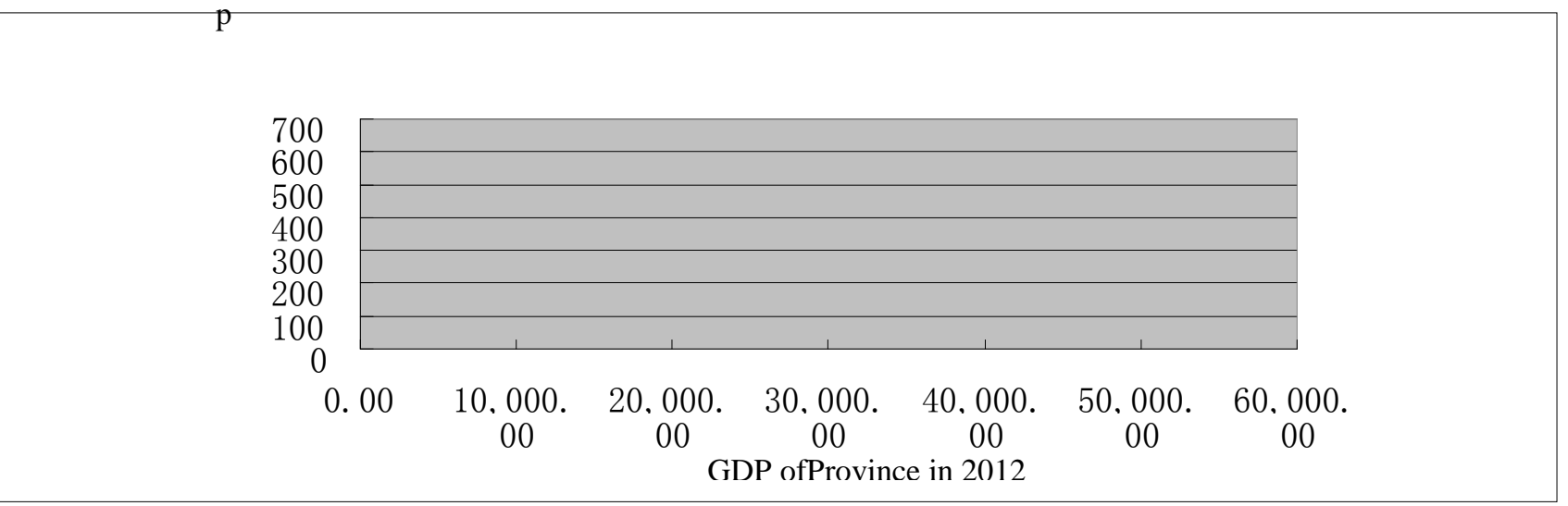

Figure 2: the relevance of GDPand public safety spending in 2012

Source: 2008-2012, 《China Statistical Yearbook》 
From table 2 and figure 4,As can be seen public safety expenditure for the provinces is essentially a positive correlation with the economic situation in the provinces, namely the ability to provide public safety services are affected by regional economic development situation. But it is worth noting that if public safety and public safety expenditure is proportional to be further tested.

It is worth noting that GDP between 1 trillion yuan to 3 trillion yuan in the province, public safety spending and economic development is not fully rendered proportional relationship, public security spending is relatively smallin some provinces that some GDP is relatively high. these provinces is Chongqing, Jilin, Shanxi, Tianjin, Jiangxi, Shaanxi, Anhui, Hunan, Hubei which are includedfive provinces in central six provinces, in addition to Chongqing and Shaanxi are also located in the central region of China.Due to located in the central region, these provincesless vulnerable to the impact of the national question, but also less vulnerable to the impact of Western thought, the public security situation compared

Table 5: GDP Per capita and expenditure of public safety per capita in 2012

\begin{tabular}{|c|c|c|}
\hline & GDP Per capita (million) & Public security spending per capita (yuan) \\
\hline Guizhou & $19,608.53$ & 419.6613 \\
\hline Gansu & $22,036.66$ & 369.3561 \\
\hline Yunnan & $22,262.58$ & 398.9697 \\
\hline Anhui & $28,840.57$ & 249.0815 \\
\hline Jiangxi & $28,851.34$ & 314.6314 \\
\hline Sichuan & $29,627.08$ & 337.5805 \\
\hline Henan & $31,753.45$ & 259.8554 \\
\hline Hainan & $32,557.13$ & 643.8557 \\
\hline Qinghai & $33,178.52$ & 703.4904 \\
\hline Hunan & $33,587.37$ & 301.8226 \\
\hline Shanxi & $33,712.25$ & 398.1999 \\
\hline Heilongjiang & $35,710.93$ & 439.228 \\
\hline Hebei & $36,700.75$ & 311.7042 \\
\hline Shanxi & $38,608.55$ & 397.1223 \\
\hline Hubei & $38,642.17$ & 353.9194 \\
\hline Chongqing & $39,256.59$ & 455.1104 \\
\hline Jilin & $43,426.05$ & 493.3455 \\
\hline Shandong & $51,897.10$ & 327.7026 \\
\hline Fujian & $52,961.77$ & 433.2711 \\
\hline Guangdong & $54,324.53$ & 586.549 \\
\hline Liaoning & $56,585.22$ & 521.3033 \\
\hline Zhejiang & $63,346.70$ & 582.4904 \\
\hline Jiangsu & $68,436.79$ & 514.8737 \\
\hline Shanghai & $85,646.91$ & 928.9076 \\
\hline Beijing & $88,167.51$ & 1144.853 \\
\hline Tianjin & $95,093.58$ & 792.0736 \\
\hline
\end{tabular}

to the west and east is better. More importantly, in the positive period of rapid economic development in central region, people's economy needs can often exceed the demand for other social needs avoid the occurrence of public safety issues that often hide a lot of social contradictions when the high-speed economic growth. So spending less than other areas of public safety in these provinces is understandable.

From the perspective of public safety spending per capita terms, according to table 5 and figure 3 , public safety expenditures per capita and GDP per capita also showed a positive correlation. And compared to expenditure of public safety of the provinces, this positive correlation is more obvious, only Qinghai, Hainan, Tianjin abnormal. Tibetan people in Qinghai are relatively more and location of Hainan island is likely to be the cause of the increase of public safety spending per capita.

Source: 2008-2012, 《China Statistical Yearbook》 


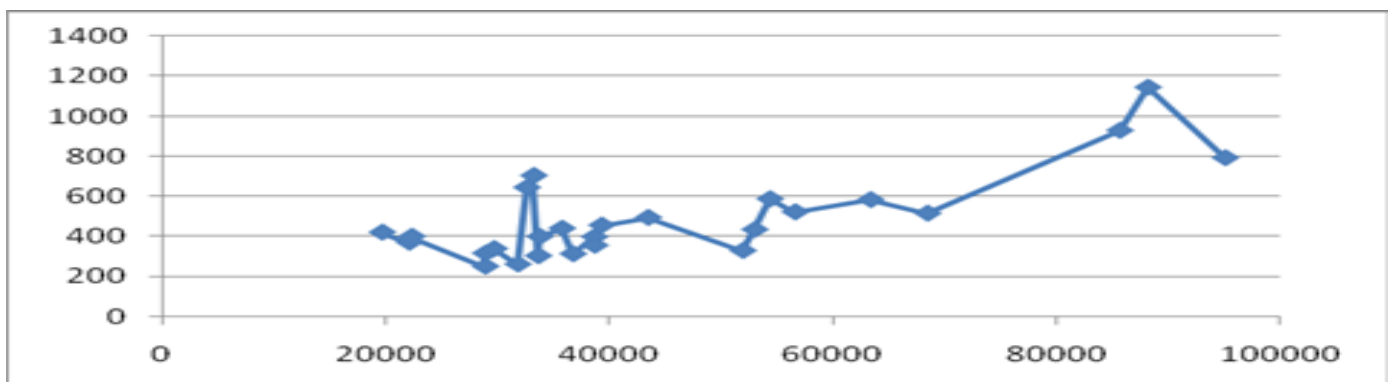

Figure 3:the relevance between GDP per capita and expenditure of public safety per capita

Source: 2008-2012, 《China Statistical Yearbook》

\section{Problems of China's public security spending}

1) The local government public safety spending overburdened

According to table 3, we can conclude that the central government spending less money on public safety expenditures, most of the responsibility for public safety spending by local governments. Under the current revenue-sharing system, the local government already exist asymmetry of service obligations and financial authority, public safety spending responsibilities of local governments exacerbated pressure on local government finances.

We derive proportional between expenditure of public safety and local economic development conclusions according to figure 2.Due to economic development and fiscal revenue in good condition, the public security spending of the eastern part is not too high a percentage of financialrevenue, namely public security spending in eastern provinces have little impact on financialrevenue of the local government.Compared to the eastern, western regions are facing greater financial burden.As follows, in 2012, the eastern coastal provinces such as Shandong, Jiangsu, Guangdong,their public safety spending accounts for less than $10 \%$ of the province's revenue. but the western inland regions such as Gansu, Qinghai,their security spending accounts for about $20 \%$ of revenue. This set of data shows that economic development of the provinces in not good conditionhas the bigger proportions, this situation affects the other public services of province, also affects the financial situation of the province.

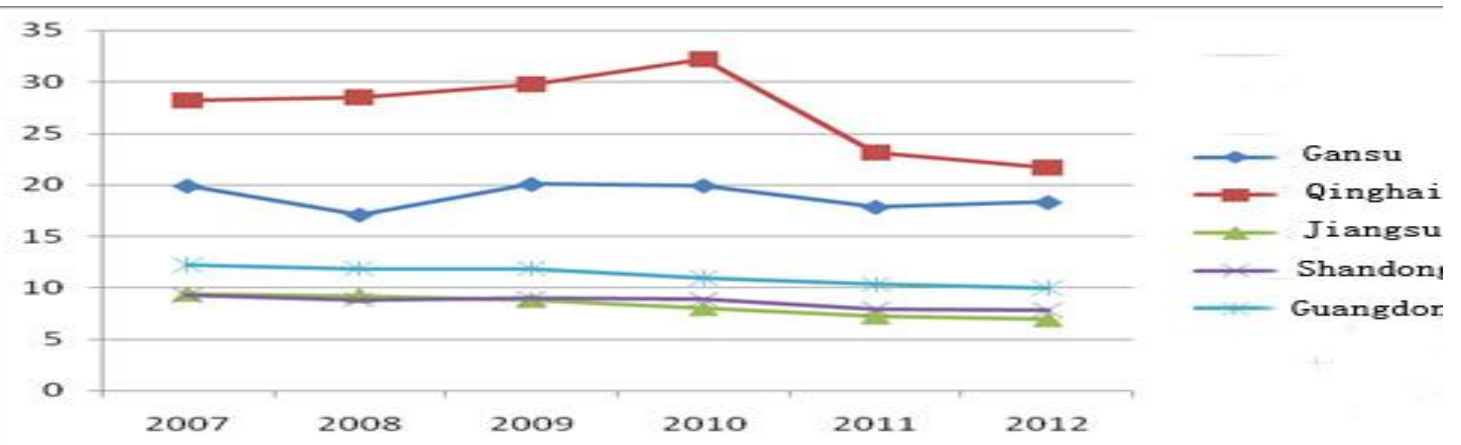

Figure 4: Public safety spending accounts for the proportion of revenue ofsome provinces between 2007-2012

Source: 2008-2012, 《China Statistical Yearbook》

2) Different public safety expenditure performance in different provinces

The results generated by public safetyexpenditure is reflected in many aspects, such as the number of mass incidents, security cases and the number of cases filed, accident rates, traffic accidents and fire accidents. This paper chooses public safety risk status indicators to measure the performance of public safety spending.

Public safety risk profile including ability and vulnerability which established by Professor Sun Huali with the principal component analysis is for evaluation of public security (the smaller, the more secure).According to Professor Sun Huali's measurements, we obtained the conclusions that public safety risks of different region have differences.

According to the data, we get figure 5 which reflects the relationship between expenditure of public safety and public safety risks. We can see from the data in figure that public safety risks related topublic safety expenditure. In other words, less expenditure of public safety areas, the public safety risk is usually relatively high, such as in the western region; on the contrary, a higher fiscal spending in areas of public safety, the public safety risk is relatively low, such as Guangdong and Shanghai City.Overall, the empirical analysis generally shows that the public safety of expenditure of the majority of local government is efficient. 
But we should also see the low efficiency of public safety spending in some provinces, such as Sichuan, Yunnan, Hebei and other places. These provinces should increase efficiency by the system design and reorganization in order to achieve the situation which don't waste people's taxes, every penny used in the right places.

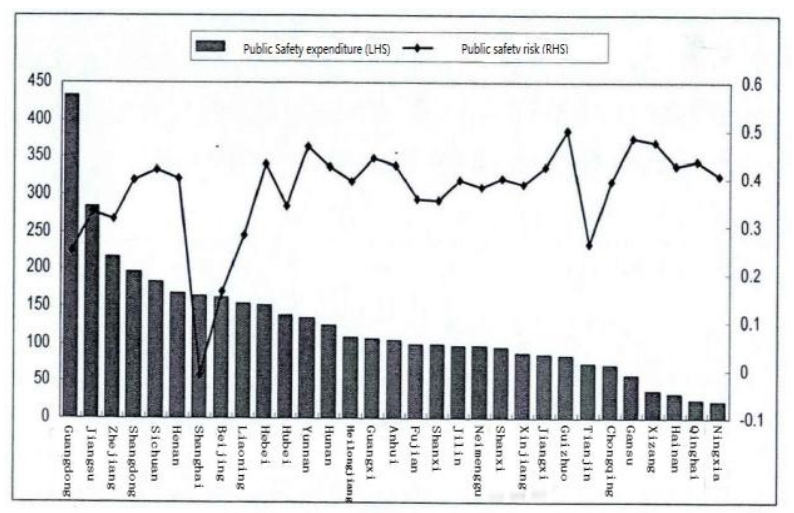

Figure 5: The expenditure of public safety and public safety risk measurement value (2009)

Source: Wu Kaiyin

\section{3) Inequality of public safety expenditures}

Life safety is the most basic and most important needs, the most important responsibility of the State and the purpose is to safeguard the existence of full and free development of each person.On the one hand, the state should protect its citizens from foreign invading withthe national defense, On the other hand, the state should also protect people from a variety of violations such as fires, accidents, security incidents, terrorist attacks and other public safety issues, reflected in the public safety spending.

Regardless of the total expenditure of public safety or public safety expenditures per capita are quite different from table 4 and table 5. In terms of expenditure of public safety per capita, Beijing's expenditure for public safety per capita is 1144.853 yuan, Anhui expenditure for public safety per capita is 249.0815 yuan, the former is about 4.6 times that of the latter. From the point of view of public security spending, Guangdong spent 62.139 billion yuan, Qinghai spent 4.031 billion yuan, the former is 15.4 times that of the latter.

4) Public safety performance fell under the background of public safety spending

Based on the above data, in recent years, the provincial public security spending growth trends were tested, the reform plan is that more public security spending should be reduced crime and social instability, but the available data suggest that causality between spending and social stability is not obvious or is weakly related.

For example, Shanghai public security spending increased 3.383 billion yuanfrom 2010 to 2012, growth rate reached 18 percent, but at the same time the security cases grow from 566,607 to 726,395 , the criminal cases increased from 119,691 to 135,682 .Under the background of public safety spending, Gansu's population rate of fire (1/10 million)from 4.21 in 2010 to 16.34 in 2012. This set of data shows theincrease of public safety spending has not brought social stability.

Table 6: security cases public security organs investigated in Shanghai from 2010to2012 (unit: cases)

\begin{tabular}{|c|c|c|c|}
\hline Category & 2010 & 2011 & 2012 \\
\hline Total & 566607 & 515163 & 726395 \\
\hline $\begin{array}{l}\text { Disrupt work or } \\
\text { public order }\end{array}$ & 25787 & 23850 & 36704 \\
\hline Gang fights & 3315 & 3190 & 3631 \\
\hline $\begin{array}{l}\text { Hinder national } \\
\text { staff perform their } \\
\text { duties }\end{array}$ & 658 & 815 & 949 \\
\hline Assaulting & 59876 & 42201 & 57764 \\
\hline $\begin{array}{lr}\text { Fraud, } & \text { robbery, } \\
\text { extortion } \\
\text { property }\end{array}$ & 24510 & 32582 & 59169 \\
\hline $\begin{array}{l}\text { Fake or Resell } \\
\text { Tickets } \\
\text { certificates }\end{array}$ & 524 & 249 & 126 \\
\hline $\begin{array}{ll}\begin{array}{l}\text { Prostitution } \\
\text { prostitution }\end{array} & \text { or } \\
\end{array}$ & 7281 & 7118 & 9771 \\
\hline Gambling & 21760 & 35722 & 51331 \\
\hline
\end{tabular}

Source: 2013, 《Shanghai Statistical Yearbook》

Table 7: criminal cases in Shanghai, 2010-2012 (unit: cases)

\begin{tabular}{|l|l|l|l|}
\hline Category & 2010 & 2011 & 2012 \\
\hline Total & 119691 & 126976 & 135682 \\
\hline Murder & 174 & 146 & 163 \\
\hline Injury & 2545 & 2711 & 2740 \\
\hline Robbery & 1558 & 1330 & 1110 \\
\hline Rape & 448 & 436 & 462 \\
\hline Fraud & 16598 & 16383 & 17885 \\
\hline Theft & 78322 & 86699 & 79245 \\
\hline Others & 20046 & 19271 & 34077 \\
\hline
\end{tabular}

Source: 2010-2012, 《 Shanghai Statistical Yearbook》

Xie Yue and Dang Dongsheng think the reason for this phenomenon is that: increase of public safety spending is more often used for staff salaries and benefits, only a very small portion is used to perform official duties; transfer payments of the central and provincial governments to upgrade infrastructure and equipment is a 
small part of the total cost of these projects, not reduced but increased the financial burden on local governments; in some poor areas, additional transfer payment has not been used for the maintenance of stability, be used to repay old debts or other purposes by local governments.

\section{CONCLUSIONS}

Through the above analysis, we can see that in recent years the public safety spending of provinces has been substantial growth, not only the public security capabilities did not materialize, but also gave the local governments more financial pressure.The reason is that the public safety services are not liable for by the central government, but for thelocal government, that will inevitably lead to local government of good economic development or good financial situation will invest more public safety spending. Overall, provinces of more public safety spending will be more secure social environment, but individual provinces which public security spending is higher appeared worse than other provinces, it is worth us to further study.

The public safety spending is an important means for the government to fulfill its most basic responsibility which protection of human lives, so need to achieve the equalization of public safety spending and fairness of public safety services. However, from the data analysis, we can see a big difference spending on public security, public safety services also appeared in a lot of unfairness.

Finally, why do the increase of public safety spending bring anti-performancegrowth, why doesn't the situation that is expected to public safety and public security expenditures are related happen? It is worth doing indepth research and study.

\section{References}

[1] Xie Yue, Dang Dongsheng . Performance Dilemma of "Maintaining stability": Public Safety Spending Perspective [J]. Journal of Tongji University, 2013 (12).

[2] Sun HuaLi, Zhou Zhanjie, Xue Yaofeng Measurement and evaluation of public safety risks based on a fishbone diagram [J]. China Safety Science .2011 (7).

[3] Wu Kaiyin. Public Safety Performance of expenditure of Local Government during Transition[D]. University of Electronic Science and Technology,2012.

[4] Xie Yue, Dang Dongsheng . Performance Dilemma of "Maintaining stability": Public Safety Spending Perspective [J].Journal of Tongji University,2013 (12). 